\title{
PRAKTEK HUKUM PENENTUAN GANTI RUGI OLEH HAKIM SEBAGAI AKIBAT ADANYA GUGATAN WANPRESTASI PADA KASUS HUTANG PIUTANG ATAU TUNTUTAN MEMBAYAR SEJ UMLAH UANG DI PENGADILAN NEGERI SURAKARTA
}

\author{
Th. Wahyu Winarto, E-mail : winartowahyu001@gmail.com \\ Mahasiswa Program Magister Ilmu Hukum Program Pascasarjana \\ Fakultas Hukum Universitas Sebelas Maret Surakarta \\ Pembimbing : \\ Hari Purwadi, E-mail : h_purwadie@yahoo.com \\ Widodo T. Novianto, E-mail : novianto@ consultant.com \\ Dosen Fakultas Hukum Universitas Sebelas Maret Surakarta
}

\begin{abstract}
This article aims to know the components and standards what is used and what legal practice used by judge District Court of Surakarta to determine punitive damages based on tort lawsuits in the dispute a debt receivable or pay an amount of money. The article is the juridical normative research. That the practice of law determining the indemnity by the judge as a result of any such tort lawsuits in case of debts receivable or demands payment of a sum of money in the District Court of S urakarta, that conclusion can be obtained in determining his little big compensation is required, the judge uses standard components and such indemnity as provided for in Article 1243 until 1252 The Book Of Civil Law (KUHPerdata) and the law is rooted in the jurisprudence. So that legal considerations in the verdict, a very dry atmosphere of juridical, sociological and philosophical. Recommendation in the context of the discovery of the law by the judge, in order to provide authoritative legal verdict, then required the preparation of material different methods of determining the law regarding the determination of the damages, and legal discovery method as a reference for judges in carrying out tasks mandated laws.
\end{abstract}

Keywords : Indemnity, Tort Lawsuit, Debt Receivable

\begin{abstract}
Abstrak
Artikel ini bertujuan untuk mengetahui komponen-komponen dan standar apa yang dipakai dan apa Praktek hukum yang dipakai oleh hakim Pengadilan Negeri Surakarta untuk menentukan ganti rugi yang didasarkan pada gugatan wanprestasi dalam sengketa hutang piutang atau tuntutan membayar sejumlah uang. Artikel ini adalah penelitian yuridis normatif. Dalam menentukan besar kecilnya ganti rugi yang dituntut, hakim menggunakan komponen dan standar ganti rugi seperti seperti yang diatur dalam Pasal 1243 sampai dengan 1252 KUHPerdata dan hukum yang digunakan adalah yang dianut dalam yurisprudensi. Sehingga pertimbangan-pertimbangan hukum dalam putusan tersebut, sangat kering dari suasana yuridis, filosofis dan sosiologis. Rekomendasinya adalah dalam konteks penemuan hukum oleh hakim, agar dapat menghasilkan putusan hukum yang berwibawa, maka diperlukan penyusunan materi berbagai metode penentuan hukum mengenai Praktek penentuan ganti rugi, dan sekaligus metode penemuan hukum sebagai acuan bagi para hakim dalam menjalankan tugas yang diamanatkan undang-undang.
\end{abstract}

Kata Kunci : Ganti Rugi, Gugatan Wanprestasi, Hutang Piutang

\section{A. Pendahuluan}

Dalam lalu lintas ekonomi, lazimnya sebuah perjanjian atau kontrak dipandang sebagai hukum bagi para pihak yang terkait dan terikat dengannya. Namun demikian, walaupun dipandang sebagai hukum, keberadaan dan berlakunya tidak boleh menyimpang dengan hukum yang lebih luas, karena hukum dalam artian tersebut adalah sangat penting untuk memperlancar dan mempermudah terjadinya interaksi berbagai kepentingan pihakpihak yang bersangkutan, kepentingan masyarakat dan kepentingan negara. Lebih dari itu, para pelaku bisnis berharap besar pada hukum, agar hukum memberikan kenyamanan, keamanan dan proteksi dalam transaksi ekonomi mereka. 
Walaupun hukum sudah berperan sedemikian rupa dalam memberikan proteksi kepada para pelaku bisnis, sangat dimungkinkan terjadinya benturan-benturan kepentingan atau pelanggaranpelanggaran terhadap perjanjian atau kontrak bisnis yang menyebabkan adanya cidera janji atau sengketa atau breach of contract, yang berujung pada sengketa bisnis atau sengketa perdata. Keadaan wanprestasi walaupun merupakan kelaziman dan mungkin sudah diprediksi akan terjadi, akan tetapi hal ters ebut sangat diharapkan tidak akan terjadi, sebab dengan adanya wanprestasi, dapat dipastikan ada pihak yang dirugikan. Sengketa bisnis atau sengketa perdata (termasuk didalamnya masalah wanprestasi), merupakan sesuatu peristiwa hukum yang tidak mungkin bisa dihindari begitu saja, karena pada dasarnya sengketa merupakan suatu cerminan dari watak dan kemauan diantara manusia yang tidak seragam (Adi Sulistiyono, 2006 : 2).

Dalam penyelesaian sengketa perdata tersebut, hukum (termasuk perjanjian atau kontrak bisnis) diharapkan mampu menyediakan mekanisme penyelesaian yang efisien dan efektif sesuai asas-asas yang berlaku dalam dunia bisnis dan ekonomi. Harapannya adalah bahwa hukum harus merupakan refleksi nilai-nilai dan prinsip-prinsip bidang ekonomi dan bisnis yang berkembang saat ini. Maka politik hukum yang terkait dengan pembangunan ekonomi diharapkan sebagai berikut (C.F.G. Sunaryati Hartono, 1991 : 30) :

"Pembangunan ekonomi sangat memerlukan sarana dan pranata hukum, supaya pembangunan ekonomi nasional benar-benar mencapai tujuan sesuai dengan rencana. Maka baik teori maupun Praktek hukum telah menjelaskan kepada kami, bahwa hukum memang mempunyai peranan yang penting khususnya untuk menjaga keseimbangan, keselarasan dan keserasian antara berbagai kepentingan dalam masyarakat dan dengan demikian memelihara kehidupan sosial yang sehat dan bersih sesuai Pancasila dan Undang-Undang Dasar 1945. "

Penyelesaian sengketa perdata mengenai tuntutan ganti rugi atas dasar gugatan wan prestasi, pada umumnya dan khususnya pada perkara hutang piutang atau tuntutan membayar sejumlah uang melalui pengadilan, mengharuskan setiap orang yang dirugikan karena wanprestasi tersebut harus mengajukan surat gugatan lebih dahulu. Dan secara empiris menjelaskan, bahwa menghadapi gugatan wanprestasi yang sekaligus menuntut dipenuhinya gantu rugi adalah bukan hal yang mudah. Bagi masyarakat pencari keadilan (baik melalui jasa advokat atau tidak), gugatan ganti rugi atas dasar wanprestasi harus dilakukan secara teliti, cermat dan kongkrit. Teliti dan cermat, dimaksudkan agar dalam merumuskan gugatan harus didalilkan adanya fakta non hukum dan fakta hukum yang tepat dan benar. Sedangkan kongkrit dimaksudkan agar, fakta non hukum dan fakta hukum serta tuntutan hukum harus didalilkan secara jelas sesuai dengan dokumendokumen atau bukti-bukti yang ada. Adapun bagi seorang hakim, pemeriksaan dan pengambilan keputusan terhadap gugatan ganti rugi atas dasar wanprestasi, memerlukan banyak pertimbangan dan asas-asas atau prinsip dasar untuk mengukur atau menghitung berapa jumlah ganti rugi yang harus diberikan terhadap adanya suatu gugatan ganti rugi, sehingga para pihak yang bersengketa merasa tidak dirugikan oleh keputusan tersebut, dan keadilan yang diharapkan dapat terpenuhi.

Dengan demikian putusan-putusan hakim tentang ganti rugi pada sengketa hutang piutang atau tuntutan membayar sejumlah uang, yang berdimensikan ketidakadilan dan merugikan, dapat menjadi pendorong timbulnya pelanggaranpelanggaran perjanjian dan mungkin perbuatan melawan hukum, karena memberikan keuntungan dan justifikasi pada tindakan-tindakan yang salah. Oleh karenanya, putusan-putusa ganti rugi yang berasaskan keadilan, merupakan cara mewujudkan ketertiban umum dan kepastian hukum yang dapat meningkatkan tertib sosial dan disiplin nasional, untuk mendukung serta memantabkan stabilitas nasional.

Pada prinsipnya asas keadilan merupakan harga mati bagi hakim dalam melakukan pertimbangan dalam putusan-putusannya, termasuk didalamnya putusan menangani tuntutan gantu rugi. Tantangan menegakkan keadilan dan kebenaran sebagaimana visi misi tersebut di atas adalah terwujudnya aturan hukumhukum yang adil serta intitusi hukum dan aparat penegak hukum yang jujur, professional dan tidak terpengaruh oleh penguasa.

S ebagai negara hukum, tuntutan masyarakat agar hukum memberi keadilan dan kepastian hukum merupakan suatu yang lumrah, karena selama ini masyarakat mendambakan hukum yang mampu menjadi sarana dan alat untuk mengayomi, memberi rasa aman dan meningkatkan kesejahteraan masyarakat. Dengan demikian sudah jelas, bahwa hukum sebagai infrastruktur pembangunan ekonomi, maka eksistensinya termasuk didalamnya keputusan hakim juga harus 
dapat dimengerti baik dari sudut ekonomi, sosial politik disamping dari sudut hukum itu sendiri" (Maruarar Siahaan, 1998 : 19). Dalam pengertian bahwa keputusan hakim disini harus mampu dan dapat dipakai acuan-acuan yang memungkinkan setiap orang, intitusi atau siapa saja memakainya sebagai sumber hukum, baik dalam tataran teoritis maupun praktis. Karena dalam putusan hakim tersebut, seringkali diketemukan asas-asas hukum atau sebaliknya asas-asas hukum telah menjelma dengan baik dalam putusan hakim.

Dalam membuat putusan, hakim harus mempertimbangkan asas-asas hukum yang tertulis dalam peraturan perundangan dan apabila belum ada asasnya, maka hakim dapat menggali asas-asas hukum yang ada dalam masyarakat. $\mathrm{Hal}$ tersebut sesuai dengan apa yang ditegaskan dalam Pasal 5 ayat (1) Undang-Undang Nomor 4 tahun 2004 tentang Kekuasaan Kehakiman, yang menengaskan bahwa: "Pengadilan mengadili menurut hukum dengan tidak membeda-bedakan orang". Mengadili menurut hukum adalah asas dalam menyelenggarakan peradilan. Suatu peradilan yang tidak dilakukan menurut hukum akan membuahkan ketidaktartiban dan peradilan yang demikian adalah batal demi hukum.

J elas sudah disini, bahwa dalam memeriksa, memutus dan mengadili perkara harus berdasarkan hukum dan juga keyakinannya, bukan berdasarkan logika hukum. Purwoto S. Gondosubroto yang ditulis oleh P. Wignyosumarto (Purwoto $\mathrm{S}$. Gondosubroto dalam P. Wignyosumarto, 2006 : 69) menyatakan :

1) Dalam kasus yang hukumnya atau undangundangnya sudah jelas, hakim hanya menerapkan hukumnya (hakim menjadi terompet undang-undang).

2) Dalam kasus yang hukum dan undangundangnya tidak atau belum jelas, hakim harus menafsirkan hukum atau undangundang, melalui cara-cara atau metode penafsiran yang berlaku dalam ilmu hukum.

3) Dalam kasus dimana terjadi pelanggaran/ penerapan hukum yang bertentangan dengan hukum/undang-undang yang berlaku, hakim akan menggunakan hak mengujinya berupa formele toetsingrecht atau meteriele toetsingrecht.

Sedangkan pengertian hukum disini tentunya meliputi hukum yang tertulis dan hukum yang tidak tertulis. Pengertian asas hukum adalah sebagai berikut (Sudikno Mertokusumo, 1986 : 10) :
"Asas hukum dapat dibagi menjadi, yakni asas hukum umum dan asas hukum khusus. Asas hukum umum adalah asas yang berhubungan dengan seluruh bidang hukum, sedangkan asas hukum khusus adalah asas dalam bidang hukum yang lebih sempit, misalnya hukum pidana, hukum perdata, hukum acara perdata dan sebagainya. "

Dengan demikian dalam melaksanakan tugasnya tersebut, yaitu mengadili perkara, hakim bukan hanya sebagai mulut atau corong undangundang, melainkan selalu harus menafsirkan atau fakta-fakta hukum yang terjadi dipersidangan, diterapkan dengan ketentuan undang-undang, sehingga mendaptkan keyakinan bahwa suatu dalil-dalil gugatan benar terbukti berdasarkan ketentuan yang berlaku.

Menurut Undang-Undang Dasar 1945 Pasal 1 dan Pasal 4 ayat (3) serta Pasal 24 dan Pasal 25 pengertian bebas tersebut meliputi kebebasan hakim untuk mengadili, bebas dari campur tangan kekuasaan lain di luar kekuasaan kehakiman. Walaupun demikian, pada kenyataannya kebebasan ini ada pembatasannya. Secara umum kebebasan tersebut dibatasi oleh sistem politik, ekonomi, budaya dan sistem pemerintahan, dan secara khusus kebebasan tersebut dibatasi oleh Pancasila, Undang-Undang Dasar 1945, UndangUndang, Ketertiban Umum atau kesusilaan serta kepentingan para pihak yang berperkara.

Disini kedudukan hakim menjadi sentral, karena hakim lah yang mempunyai kewenangan untuk menentukan besar kecilnya ganti rugi dalam putusannya. Dalam membuat keputusan tersebut, hakim harus memberikan keadilan kepada semua pihak. Hal ini dapat dimengerti, sebab dalam banyak perkara atau gugatan ganti rugi terkait erat dengan adanya pelanggaran-pelanggaran kontrak bisnis yang dilakukan oleh para pelaku ekonomi, baik yang sifatnya nasional maupun internasional.

Mengenai ganti rugi itu sendiri, memang tidak ada satu pun ketentuan hukum yang secara khusus dan tegas mengatur mengenai ganti rugi terkait adanya gugatan wanprestasi. Satusatunya aturan yang dapat dirujuk mengenai hal tersebut adalah beberapa pasal yang terdapat dalam Kitab Undang-Undang Hukum Perdata (KUHPerdata) yaitu dalam Pasal 1243 sampai dengan Pasal 1252. Namun dalam pasal-pasal ini hanya disinggung mengenai istilah "biaya", "ganti rugi", dan "bunga". Mengenai metoda, komponenkomponen penentuan ganti rugi sama sekali tidak diatur. Dalam menentukan besar kecilnya ganti 
rugi dalam sengketa hutang piutang atau tuntutan membayar sejumlah uang, umumnya hakim tidak mau repot-repot terjebak dalam perhitungan yang "njlimet", melainkan hanya menentukan bentuk kerugian-kerugian yang nyata dan dapat dihitung berdasarkan bukti-bukti kongkrit berupa akta notaris, yang terkait dengan keadaan wanprestasi.

Berdasarkan hal-hal tersebut di atas, hendak dibahas bagaimana Praktek Putusan Penentuan Ganti Rugi oleh Hakim yang Didasarkan pada Gugatan Wanprestasi dalam Sengketa Hutang P iutang atau Tuntutan Membayar Sejumlah Uang di Pengadilan Negeri Surakarta.

\section{B. Metode Penelitian}

Penelitian yang akan digunakan adalah Penelitian Normatif dengan Metode Doktrinal. Penelitian ini untuk mengetahui komponenkomponen dan standar apa yang dipakai dan mengetahui apa Praktek hukum yang dipakai oleh hakim Pengadilan Negeri Surakarta untuk menentukan ganti rugi yang didasarkan pada gugatan wanprestasi dalam sengketa hutang piutang atau tuntutan membayar sejumlah uang. J enis data yang digunakan adalah Data Sekunder, yang terdiri dari : bahan hukum primer, sekunder dan tersier, sedangkan sumber datanya berasal dari peraturan perundang-undangan, studi kepustakaan, bahan-bahan dokumenter, tulisantulisan ilmiah dan sumber-sumber tertulis lainnya.

\section{B. Hasil Penelitian Dan Pembahasan}

Gugatan-gugatan ganti rugi yang didasarkan pada titel wanprestasi pada kasus hutang piutang atau tuntutan membayar sejumlah uang, menurut P raktek dapat terjadi karena adanya pelanggaran atas suatu perjanjian yang dilakukan oleh salah satu pihak, sehingga menimbulkan kerugian di pihak lainnya. Pihak yang menderita kerugian, kemudian mengajukan tuntutan atau gugatan ganti rugi atas dasar wanprestasi kepada pihak yang melakukan pelanggaran atau cidera janji melalui Pengadilan Negeri setempat.

Alasan-alasan hakim untuk menyatakan bahwa seseorang Tergugat (Debitur) wanprestasi adalah didasarkan pada hal-hal sebagai berikut:

a. Adanya pelanggaran atas perjanjian hutang atau kesanggupan membayar yang dimuat dalam akta notaris atau perjanjian pengakuan hutan, sehingga menyebabkan adanya wanprestasi.

b. Adanya akta notaris atau surat pengakuan hutang yang oleh hakim dinilai sebagai alatbukti yang sempurna dan mempunyai kekuatan mengikat bagi hakim.

c. Adanya perhitungan ganti rugi yang dikabulkan oleh hakim.

Selanjutnya atas hal-hal tersebut di atas dilakukan analisis melalui proses search and research dalam penemuan hukum in concreto melalui tahapan (Bambang Sunggono, 2003 : 94), yaitu :

"1. Proses yang dikenal sebagai searching for the relevant facts yang terkandung dalam perkara hukum yang tengah dihadapi (sebagai bahan premis minor).

2. Proses searching for the relevan abstract legal prescription yang terdapat dan terkandung dalam gugus hukum positif yang berlaku (sebagai bahan premis mayor)."

Dengan demikian norma-norma hukum yang terdapat dan dipositipkan sebagai hukum dan pertimbangan-pertimbangan hukum yang dibuat oleh hakim dalam setiap putusannya, dapat digunakan untuk menyelesaikan perkara yang dihadapinya.

1. Pertimbangan Hukum Putusan Pengadilan Mengenai Ganti Rugi Akibat Wanprestasi Dipandang dari Aspek Asas-Asas Perjanjian

Penting kiranya atas alasan-alasan pertimbangan hukum dalam putusan Pengadilan Negeri S urakarta tersebut di atas, peneliti analisis dari aspek hukum positif yang berlaku yang berisikan nilai-nilai, asas-asas hukum yang terkait dan yang berlaku sebagai premis mayornya, guna mengetahui apakah nilai-nilai hukum yang berlaku sebagai premis mayor tersebut dijadikan acuan oleh hakim sebagai bahan pertimbangan dalam membuat putusan dalam menyelesaikan sengketa tuntutan ganti rugi dalam sengketa hutang piutang atau tuntutan membayar sejumlah uang.

\section{a. Dipandang dari Asas Kebebasan Berkontrak}

Dari aspek ini, kesepakatan sebagai salah satu unsur sahnya perjanjian seharusnya dilihat secara seksama, apakah sebuah kesepakatan itu merupakan perwujudan dari kehendak bebas kedua belah pihak atau bertentangan dengannya. Sebagaimana ketentuan Pasal 1321 KUHPerdata, yang apabila dicermati dapat disimpulkan 
bahwa suatu sepakat yang sah adalah apabila ia lahir bebas dari berbagai bentuk rekayasa yang bertujuan merugikan pihak lain seperti tekanan, paksaan, penipuan dan penyalahgunaan keadaan. Sejalan dengan jiwa pasal ini, bahwa kesepakatan harus dapat dilihat sebagai suatu persesuaian kehendak dan kedua belah pihak harus mempunyai kehendak untuk mengikatkan diri serta harus bebas dari paksaan (ketakutan), kesesatan atau penipuan.

Dalam pertimbangan hukumnya para hakim yang mengabulkan tuntutan ganti rugi atas dasar wanprestasi, tampak tidak menjadikan asas kebebasan berkontrak sebagai unsur penting dalam menilai fakta peristiwa kongkritnya. Hakim berhenti pada menemukan peristiwa kongkrityang telah terbukti. Ia hanya menemukan fakta obyektif demikian adanya, namun tidak melakukan penilaian dan pemaknaan atas fakta yang ada. Terlebih lagi, fakta yang membuktikan terdapatnya peristiwa kongkrit itu berbentuk akta notaris, yang karenanya hakim merasa terikat dengannya sebagai alat bukti yang mempunyai kekuatan hukum sempurna.

Berhentinya sikap hakim terbatas pada menemukan sejumlah fakta yang dinilainya sudah terbukti, tidak sejalan jika dilihat dari aspek teoritis mengenai arti dan tuiuan pembuktian. Sudikno Mertokusumo yang mengatakan : "Membuktikan berarti menetapkan peristiwa hukum, tetapi juga dalam arti luas menetapkan hubungannya sendiri", dan selanjutnya dikatakan: "Membuktikan ialah memberi kepastian kepada hakim tentang peristiwa-peristiwa hukum dengan alat-alat tertentu untuk dapat mengabulkan akibat hukum yang dihubungkan dengan peristiwa-peristiwa itu oleh hukum (Sudikno Mertokusumo, 1984 : 188), dengan alasan memberikan pemahaman bahwa suatu peristiwa kongkrit setelah dikonstruksi menjadi peristiwa hukum, apalagi dikaitkan dengan nilai hukum di dalamnya telah melibatkan nilai-nilai hukum. Nilai-nilai hukum esensinya adalah perlindungan atas kepentingan manusia, berdasarkan Undang-Undang No. 4 Tahun 2004. Pasal 1, 3 ayat (2) dan Pasal 4 ayat (1) memiliki rujukan pada Pancasila dan Keadilan berdasarkan Ketuhanan Yang Maha Esa.

Sebagaimana pula ketentuan Pasal 28 ayat (1) UU tersebut, merupakan dasar bagi Hakim untuk menemukan nilai-nilai hukum. Dalam hal ini hakim dalam menilai perjanjian dimaksud, seharusnya melakukan penilaian, apakah materi bukti-bukti dalam bentuk akta notaris atau dalam bentuk fakta-fakta riil, berkesesuaian dengan nilai-nilai hukum atau tidak. Dengan hanya menyandarkan pada kekuatan bukti akta notaris, hakim telah menetapkan bahwa para pihak terikat dengan a pa yang telah disepakati. Disini hakim hanya melakukan penilaian terhadap bukti-bukti formal yang ada dan tidak sampai pada langkah untuk membandingkan secara kritis berbagai fakta dan peristiwa kongkrit.

b. Dipandang dari Aspek Asas Etiket Baik

Asas itikad baik di atur di dalam Pasal 1338 ayat (3) KUHPerdata, pada prinsipnya asas ini merupakan nilai moral dalam hukum perdata. P embentuk undang-undang dalam ayat 1 pasal yang sama memberikan kebebasan (asas kebebasan berkontrak) untuk melakukan berbagai transaksi. Namun dengan adanya asas itikad baik ini, asas kebebasan berkontrak mengalami pembatasan secara moral. Mencermati kalimat dalam Pasal 1338 ayat (3) yang berbunyi : "Persetujuan (perjanjian) harus dilaksanakan dengan itikad baik", maka menurut hemat peneliti asas ini selalu menyertai setiap perjanjian. Artinya pasal 1338 ayat (3) tersebut dicantukam atau tidak dalam sebuah perjanjian, maka berlakunya perjanjian dimaksud tetap saja harus memperhatikan substansi pasal tersebut. Konsekuensinya adalah bahwa asas ini bersifat "built in" dalam suatu perjanjian, dalam pengertian berlakunya asas ini memerlukan upaya fungsionalisasinya secara aktif. Dalam hai ini, hakim berkewajiban untuk itu. J ika kenyataannya terdapat isi perjanjian yang melanggar asas ini dengan akibat tidak seimbangnya bobot dan kualitas prestasi masing-masing pihak, maka asas itikad baik seharusnya difungsikan sebagai faktor untuk menambah, melengkapi, 
membatasi atau meniadakan isi perjanjian. dengan maksud agar isi perjanjian benarbenarsesuai dengan apa yang merupakan kehendak bebas para pihak.

Asas itikad baik yang seharusnya menjadi roh bagi mereka yang terikat dengan perjanjian hutang piutang sebagaimana yang menjadi sengketa dalam kasus-kasus di atas. Artinya situasi dan kondisi yang muncul karena wanprestasi harus dipertimbangkan sedemikian rupa, sehingga faktorfaktor yang mempengaruhinya dapat diungkapkan dengan jelas dan dapat dipahami serta disadari oleh para pihak. Dalam kasus-kasus di atas, hakim terikat dengan akta notaris yang dipandang sebagai bukti sempuma dan meyakini bahwa wanprestasi muncul oleh karena tenggang waktu pembayaran hutang telah jatuh tempo atau kesanggupan membayar telah jatuh tempo dan karenanya debitur tidak mampu membayar hutanghutangnya. Padahal tentang kapan seseorang dinyatakan wanprestasi pada tahun 1959 Mahkamah Agung RI melalui jurisprudensinya, telah menempatkan diri tidak sebagai corong undang-undang, akan tetapi telah melakukan diskrisioner dengan mengaskan bahwa : Wanprestasi baru ada pada saat dinyatakan secara tertulis oleh pihak kreditur, walaupun dalam perjanjian ditentukan tenggang waktunya. Dengan demikian mencermati jurisprudensi tersebut dan membandingkannya dengan putusan hakim dalam sengketasengketa tersebut, maka dapat dikatakan bahwa hakim yang menentukan bahwa seseorang telah wanprestasi karena tidak sanggup membayar hutang atau membayar sejumlah uang pada waktu yang telah diperjanjikan, bukanlah hal yang bijak. Karena hakim tersebut sama sekali tidak mempertimbangkan hal-hal yang ada dibalik keadaan kongkrit, yang menyebabkan seseorang debitur tidak dapat membayar hutang atau membayar sejumlah uang sesuai kesanggupannya atau waktu yang telah ditentukan. Hakim dalam hal ini tidak mempertimbangkan nuansa nilai-nilai moral dalam arti asas itikad baik, padahal kekuatan moral suatu putusan hakim terletak pada pertimbangan-pertimbangan hukumnya. c. Dipandang dari Aspek Asas Causa yang Halal

Causa (sebab) yang halal sebagai syarat ke empat sahnya suatu perjanjian sebagaimana ketentuan Pasal 1320 KUHPerdata, melalui Pasal 1337 KUHPerdata dapat diperoleh pengertian sebaliknya yaitu bahwa causa yang tidak halal adalah apabila dilarang oleh undangundang. Hal ini membawa implikasi hukum bahwa penafsiran terhadap causa yang halal memerlukan kecermatan, ketelitian dan kehatian-hatian dalam menentukan ukuran-ukurannya. Secara empiris dapat dikemukakan bahwa ukuranukuran causa yang halal yaitu disamping bertentangan dengan undang-undang, juga bertentangan dengan ketertiban dan kesusilaan seperti bertentangan dengan nilai-nilai positif yang hidup dalam masyarakat luas, bertentangan dengan kewajiban yang sudah tertentu berdasarkan kebiasaan, sesuatu yang seharusnya dibuat manusia, sesuatu yang bertentangan nilai-nilai hidup berbangsa dan bernegara, ikatan agama dan tata krama berkeluarga.

Dengan adanya ukuran-ukuran diatas, diperoleh pengertian bahwa konsep causa yang halal tidak dapat dipisahkan dari sistem nilai yang bersifat suci dan utama, bahkan antara keduanya memerlukan langkah untuk mensenyawakan. Dengan demikian suatu perjanjian agar tujuannya mencerminkan sifat dasar dan apa yang disebut hukum, perlu diletakkan dalam pendekatan nilai suci dan utama yang terdapat dalam institusi masyarakat, tradisi, bangsa dan agama.

Pertimbangan hakim dalam perkara tetap mengesahkan jual beli yang dilakukan oleh kreditur dan menyatakan bahwa debitur telah melakukan wanprestasi. Akan tetapi anehnya, hakim yang telah menyatakan wanprestasi tersebut, tidak mengabulkan tuntutan ganti rugi yang dituntut oleh Penggugat Rekonpensi, sehingga menurut hemat peneliti putusan tersebut menjadi tidak jelas dan bertentangan antara putusan bagian konvensi dan putusan bagian rekonpensi. Disini hakim tidak memberikan penilaian apakah jual beli terhadap barang jaminan, yang dilakukan oleh krditur tersebut telah 
dilakukan dengan sesuai isi perjanjian atau apakah jual beli berdasarkan surat kuasa menjual tersebut bertentangan prestasi debitur atau apakah hal tersebut bertentangan dengan undang-undang, ketertiban dan kesusilaan. Padahal apa yang ditentukan dalam Pasal 25 UU No. 4 Tahun 2004 yang mengharuskan hakim untuk mendasarkan pada sumber hukum tertulis dan tidak tertulis, ternyata hanya menunjukkan bahwa hukum tertulis saja yang dijadikan dasar putusannya. Dan inipun tidak dibandingkan dengan undang-undang yang lain yang relevan. Hukum tidak tertulis yang kaya akan berbagai nilai-nilai hukum tidak pula dijadikan pertimbangan. Dengan demikian pertimbangan hukumnya kering dari muatan nilai-nilai filosofis dan sosiologis.

Padahal dalam suatu perjanjian tidak sah apabila tidak mengandung causa atau mengandung causa yang tidak halal. Pada alasan hakim di atas, terdapat pembenaran secara hukum atas bukti-bukti notariil, yang is inya tidak ditafsirkan apakah perjanjian itu memiliki causa yang halal atau tidak. Dalam hal ini hakim melihatnya dari arti yang luas mengenai causa yang halal, ia seyogyanya menafsirkan secara tajam, apakah causa perjanjian yang terdapat di dalam akta tersebut bertentangan atau tidak dengan undang-undang, ketetiban umum dan kesusilaan.

d. Putusan Pengadilan Ditinjau dari Aspek Kebebasan Hakim

Majemuk dan kompleksnya jenis kepentingan dari berbagai kelompok sosial maupun individual sebagai suatu realitas, perlu dipahami sebagai salah satu faktor yang merupakan alasan pentingnya penemuan hukum (rechtsvinding), khususnya oleh hakim. Semakin kompleks kemajemukan kepentingan, semakin kompleks pula kemajemukan kebutuhan hukumnya. Dalam konteks tersebut, maka penyediaan hukum sebagai fasilitator diperlukan untuk memberikan perlindungan dan keadilan bagi masyarakat atas berbagai kepentingannya, yang sekaligus diharapkan dapat mencerminkan keadilan berdasarkan undang-undang maupun keadilan yang bersifat perorangan. Penemuan hukum akan semakin bermakna jika dihadapkan pada kebutuhan hukum yang bersifat perorangan, mengingatbeberapa alasan, yaitu : Pertama, undang-undang tetap dalam lalu lintas kepentingan individu dan sosial berkembang lebih cepat dan kompleks. Dalam konteks ini, hakimhakim bukan sekedar "broche de la lot", tetapi menjadi penterjemah atau pemberi makna melalui penemuan hukum (rechtschepping) bahkan menciptakan hukum baru melalui putusan-putusannya (judge made law) (Bagir Manan, 2005 : 23).

Dengan demikian penemuan hukum yang dilakukan oleh hakim dimaksudkan untuk menghasilkan suatu putusan yang dapat menyelesaikan sengketa, idealnya, putusan hakim dapat mengandung muatan nilai keadilan, kepastian hukum, dan kemanfaatan. Dalam kaitan ini, arti "menyelesaikan sengketa", perlu dipahami secara kritis, yaitu bukan sekedar menyelesaikan secara prosesuil, namun dengan putusan hakim, hak-hak dan kewajiban para pihak, secara hukum dapat ditetapkan secara proporsional. Dengan demikian, putusan hakim dapat mencerminkan salah satu fungsi hukum, yaitu sebagai pemberi kepastian, pengaman, pelindung dan penyeimbang (Lili Rasjidi dan I.B. Wyasa Putra, 1993 : 123). Menilik putusan hakim Pengadilan Negeri Surakarta yang memberikan putusan sama dan sebangun dalam masalah wanprestasi atas dasar perjanjian notariil dan bawah tangan maupun pada tuntutan membayar sejumlah uang, yaitu mengabulkan gugatan ganti rugi atas dasar wanprestasi yang bersandarkan pada bukti-bukti autentik/notariil atau akta bawah tangan saja. Ini menunjukkan bahwa hakim dalam memberikan pertimbangan-pertimbangan pada putusannya tidak mempunyai keberanian untuk melakukan langkah-langkah baru yang mengindikasikan adanya penemuan hukum. Mereka lebih bersikap patuh pada undang-undang, patuh pada perjanjian yang dibuat para pihak, dan cenderung mencari aman. Dalam hal ini 
tampak hakim sekedar sebagai corong undang-undang atau perjanjian yang dibuat para pihak. Hakim berhenti pada kebenaran faktual, dan karenanya belum mencerminkan kebenaran hukum yang seutuhnya. Padahal tugas hakim adalah menemukan seberapa jauh fakta-fakta yang ada padanya dapat dicocokkan dengan definisi yang abstrak dan umum dari undang-undang. Putusan hakim disini hanya dipahami dari segi logis yuridis dan tidak ada proses selektif dan kreatif, dimana hakim tidak begitu saja berhenti kepada kebenaran faktual, yang belum tentu mencerminkan kebenaran hukum. Atau dengan kata lain, dalam hal-hal tertentu hakim harus lebih menggunakan pendekatan kontekstual, bukan tekstual. Hakim lebih dituntut untuk bukan saja aktif dan proaktif, namun juga sekaligus progesif (Qodri Azizy, 2006 : XI).

Dalam hal ini tampak bahwa fakta-fakta yang ditemukan hakim, tidak diberi arti umum sesuai dengan jiwa dan tujuan undang-undang yaitu melindungi kepentingan umum. Hakim dalam putusan-putusan tersebut, sekan mengabaikan sumber-sumber untuk menemukan hukum, yang dalam konteks Indonesia adalah : Perundangan-undangan, hukum tidak tertulis, putusan desa, yurisprudensi dan ilmu pengetahuan hukum (Sudikno Mertokusumo, 1985 : 166). Dilihat dari model penemuan hukum yang heteronom, seharusnya hakim terikat dengan undang-undang, dalam kaitan kasus ini, ia terikat dengan bukti otentik yaitu akta notaris. Konsekuensinya, ia seharusnya mengesahkan perjanjian hutang piutangnya. Akan tetapi apabila kita menyimak beberapa yurisprudensi, tampak adanya perjanjian hutang piutang yang dibatalkan. Dan menurut hemat peneliti, ini menunjukkan bahwa hakim di Indonesia tidak sepenuhnya mencerminkan model heteronom. Dalam pengertian tersebut judex juris, dengan sikapnya yang selektif atas peristiwa kongkrit yang telah ditemukannya, kemudian diberi arti dan selanjutnya ditarik relevansi maknawiahnya dengan undang-undang yang dinilainya paling benar dan cocok serta proporsional, dapat dikatakan adanya persesuaian dengan model penemuan hukum otonom.

Penemuan hukum sebenarnya merupakan jawaban atas berbagai permasalahan yang menuntut penyelesaian secara hukum. Oleh sebab permasalahan selalu bersifat dinamis, maka penemuan hukum itu sendiri merupakan dinamika pemikiran mengenai hukum, terutama dari hakim. Hakim bukan saja merupakan jabatan yang mencerminkan watak kebebasan dan kemandirian bahkan keberanian untuk mengambil keputusan, tetapi merupakan keahlian (profesi) yang ideal dan strategis untuk mewujudkan judge made law. Hal ini mengingat bahwa ia memiliki otoritas dan kemampuan akademik di bidang ilmu hukum dan hukum yang sekaligus merupakan pekerja lapangan yang selalu berhadapan dengan berbagai fakta empiris yang kompleks. Hakim adalah legal problem solver akademik dan nilai-nilai yuridis, dengan orientasinya pada pencapaian kebenaran dan kesejahteraan umat manusia. Dalam rangka demikian ia tidak dapat sekedar mengikuti jenis penemuan hukum yang legistis dimana ia terikat dengan dan sekaligus corong undang-undang yang mencerminkan model heteronom itu. Untuk memperoleh penemuan hukum yang bermuatan nilai-nilai filosofis, sosiologis dan yuridis, maka hakim harus memahami tujuan masyarakat dan perkembangan sejarah sebagai sarana pembantu dalam menentukan hukum. Untuk itu agar putusan hakim dapat mencerminkan hukum yang dianggap adil dalam masyarakat, hakim perlu diberi kebebasan untuk memperhatikan semua unsure kongkrit dan situasi sosial yang dihadapinya.

Dengan demikian dalam menentukan besar kecilnya ganti rugi yang harus diberikan sebagai akibat adanya gugatan wanprestasi, maka hakim diberikan kebabasan untuk menentukannya. Kebebasan hakim dalam system hukum ketatanegaraan kita, dapat kita ketahui dari bunyi Pasal 24 Undang-Undang Dasar 1945 dan Pasal 1 Undang-undang No. 4 tahun 2004 tentang Kekuasaan 
Kehakiman ditegaskan bahwa: "Hakim mempunyai kemerdekaan (kebebasan) untuk menyelenggarakan peradilan guna menegakkan hukum dan keadilan". Dengan demikian fungsi mengadili di Pengadilan tersebut hanya dilakukan oleh hakim. Dalam melaksanakan fungsinya tersebut sesuai Pasal 5 ayat (1) Undang-undang No. 4 tahun 2004, ditentukan yaitu : "Pengadilan mengadili menurut hukum dengan tidak membedabedakan orang".

2. Komponen dan Standar Penentuan Ganti Rugi oleh Hakim

a. Komponen ganti rugi oleh hakim

Sebagaimana telah dibahas di depan bahwa ruang lingkup adalah meliputi : biaya, rugi dan bunga, hakim dalam perkara tersebut dalam menentukan komponen ganti rugi juga tidak lepas dari ruang lingkup yang ada. Adapun komponen ganti rugi yang ditentukan oleh hakim dalam perkara-perkara tersebut adalah sebagai berikut:

1) Kerugian yang nyata (damnum emergens/kosten)

Hakim Pengadilan Negeri Surakarta dalam pertimbangan putusannya, memaknai kerugian yang nyata terbatas pada hutang pokok atau yang menjadi kesanggupan debitur yang belum dibayar dan dikuatkan dengan bukti autentik seperti akta notaris. Hakim dalam perkara tersebut, sama sekali tidak memperhitungkan keseluruhan biaya-biaya riil yang dikeluarkan oleh kreditur yang menderita kerugian akibat wanprestasi yang dilakukan oleh debitur, seperti biaya transportasi, biaya akomodasi, biaya jasa advokat, biaya pembuatan akta notaris dan lain-lain yang secara langsung mengurangi kekayaan kreditur.

\section{2) Kerugian}

Sedangkan tentang keuntungan yang hilang oleh hakim lazimnya juga didasarkan rincian gugatan yang menjelaskan secara rinci besarnya mengenai keuntungan penggugat yang dituntut, tanpa ada rincian yang jelas dan tidak didukung bukti-bukti yang kuat untuk itu, maka tuntutan mengenai keuntungan tidak dapat dibenarkan.

3 Bunga

Dalam Praktek hakim akan mempertimbangkan tuntutan bunga dengan prinsip yaitu : apakah lazim bunga yang dituntut tersebut telah ditetapkan dan diperjanjikan atau tidak diperjanjikan. A pabila tuntutan mengenai bunga tersebut terbukti telah diperjanjikan, maka lazimnya tuntutan bunga yang dikabulkan oleh hakim adalah bunga sesuai perjanjian. Ini dapat dilihat dalam beberapa jurisprudensi yaitu :

- No. $340 \mathrm{~K} / \mathrm{Sip} / 1971$ tanggal 7 Juli 1971 : Tuntutan pembayaran bunga sebesar $20 \%$ berdasarkan perjanjian patut dikabulkan.

- $\quad$ No. 994 K/Sip/1973 tanggal 26 Nopember 1975 : Karena telah diakui oleh penggugat Kasasi/ tergugat asal bahwa yang dibayar berturut-turut sampai lima kali adalah 9\%, maka bunga tersebut telah disetujui oleh kedua belah pihak.

Sedangkan terhadap tuntutan bunga yang tidak diperjanjikan, maka bunga diperhitungkan adalah bunga yang ditetapkan oleh pemerintah yaitu $6 \%$ setahun (J urisprudensi No. 804 K/Sip/1973 tanggal 4 Desember 1975 dan No. $994 \mathrm{~K} / \mathrm{Sip} / 1973$ tanggal 26 Nopember 1975) atau sebesar bunga bank-bank pemerintah pada waktu itu (J urisprudensi No. 1399 K/ Sip/1975 tanggal 13 Mei 1975 No. $1163 \mathrm{~K} / \mathrm{S}$ ip/1973 tanggal 20 Agustus 1975.

b. Standar penentuan ganti rugi oleh hakim Sebagaimana disinggung dalam bagian pendahuluan bahwa persoalan penentuan ganti rugi yang diatur dalam Pasal 1243 sampai dengan Pasal 1252 Kitab Undang-Undang Hukum Perdata hanya menyinggung soal biaya, ganti rugi dan bunga dan tidak mengatur secara kongkrit mengenai asas-asas, cara-cara atau metoda-metoda tentang penentuan ganti rugi harus dihitung, begitu juga dengan komponen-komponen serta 
analisa apa yang harus digunakan oleh hakim. Mengenai hal tersebut diserahkan kepada kewenangan hakim untuk melakukan sesuai keyakinannya dan memberikan keputusan yang seadiladilnya. Dalam penentuan besar kecilnya ganti rugi yang didasarkan pada gugatan wanprestasi, masyarakat berharap agar para hakim memberikan pertimbangan dalam putusan hukumnya secara adil sehingga terdapat harmonisasi antara hukum tertulis yang diatur dalam undangundang dengan hukum yang riil yang hidup dalam masyarakat. Dengan demikian jika mencermati Pasal 1243 sampai dengan Pasal 1250 KUHPerdata, tentang ganti kerugian tersebut tidak ada satu petunjuk yang dapat dipedomani, bagaimana cara yang ditempuh agar dapat dihitung ganti rugi yang tepat yang akan mencakup kerugian seseorang secara tidak berlebihan, sehingga dapat dipandang bahwa dia telah ditempat pada posisi yang seharusnya dicapainya seandainya perjanjian terlaksana. $\mathrm{Hal}$ ini tentu menunjukkan bahwa cara yang ditempuh adalah dengan lebih dahulu merinci daftar kerugian yang telah terjadi, baik yang menyangkut kerugian yang dialami nyata sebagai akibat wanprestasi maupun keuntungan yang hilang. J urisprudensi mengenai hal tersebut dapat ditempuh sekedar menyangkut perlunya kerugian tersebut dirinci dan tanpa perincian maka gugatan ganti rugi semacam itu tidak dapat diterima. Perhitungan kerugian secara abtrak dilakukan dengan mana pos-pos kerugian ditetapkan atas suatu jumlah yang dinilai secara umum, terlepas dari keadaannya yang khusus.

Praktek menunjukkan bahwa soal tuntutan ganti rugi harus didalilkan dan dituntut dalam gugatan secara tegas. Apabila tidak dilakukan penuntutan, maka suatu putusan hakim dengan pertimbangan hukum apapun, yang mengabulkan hal tersebut tidak dapat dibenarkan (J urisprudensi Mahkamah Agung RI No. 689 K/Sip/1974 tanggal 2 Nopember 1976 jo No. 1079 K/ Sip/1973 tanggal 26 Pebruari 1979). Bahkan J urisprudensi Mahkamah Agung RI No. 1575 K/Sip/1974 tanggal 22
Agustus 1976 menegaskan : “Keputusan Pengadilan Tinggi yang mengabulkan tuntutan mengenai ganti rugi hanya atas pertimbangan "karena tidak dibantah dapat dikabulkan" tidak dapat dibenarkan, karena hal tersebut ternyata belum diperiksa, gugatan ganti rugi ini harus dinyatakan tidak dapat diterima". Sedangkan penentuan kerugian yang nyata dalam gugatan wanprestasi, selalu didasarkan pada hal-hal yang secara umum telah diketahui rincian atau pos-pos kerugian. Hakim disini hanya meneliti, memeriksa dan menilai besar kerugian yang diderita kreditur secara umum, yang diposisikan Penggugat dalam suatu gugatan wanprestasi. $\mathrm{Hal}$ tersebut harus dilakukan oleh hakim, karena dalam prinsip ex aequo et bono kerugian yang sangat nyata harus diberikan oleh hakim (menurut J urisprudensi Mahkamah Agung RI No. 1195 K/Sip/1973 tanggal 9 September 1976 menengaskan bahwa : "Penentuan besarnya ganti rugi adalah bersifat kenyataan dan karenanya tidak tunduk pada kasasi".

Hakim tidak begitu memperhitungkan keadaan kongkrit yang bersangkutan secara subyektif, tetapi ia meneliti berapa besar kerugian yang berpiutang secara umum, yaitu seorang yang menduduki posisi yang serupa dengan penggugat. Kerugian, dalam hal ini disamakan dengan pengurangan yang telah dihitung secara obyektif, yang dilakukan atas kekayaan orang terhadap siapa yang telah dilakukan cidera janji. J adi dalam hal ini, yang dihitung oleh hakim dalam kasus-kasus tersebut adalah kerugian dalam kenyataannyalah yang harus diganti, yaitu hutang pokok dan bunga yang belum dibayar atau diperhitungkan. Dalam hal ini hakim-hakim tersebut dalam pertimbangan hukumnya tidak mempertimbangkan keadaan-keadaan kongkrit lain, selain akibatumum dengan adanya wanprestasi, semisal biaya-biaya yang dikeluarkan sebelum perjanjian dibuat atau sebelum seseorang menyatakan kesanggupannya untuk membayar sejumlah uang, seperti biaya perjalanan, biaya akomodasi atau biayabiaya lainnya terkaiat dengan realisasi 
sebuah hubungan hukum yang akan diadakan.

Praktek yang ditemukan dalam juris prudensi, metode yang dipakai untuk menghitung ganti rugi adalah berdasarkan kenyataan yaitu menghitung secara subyektif kerugian-kerugian yang dialami termasuk kerugian-kerugian tambahan yang dapat diperhitungkan secara masuk akal, dalam arti tidak bertentangan dengan keadilan dan kemanusiaan. $\mathrm{Hal}$ ini seperti tercermin dalam jurisprudensi No. $1253 \mathrm{~K} / \mathrm{S} \mathrm{ip} / 1973$ tanggal 14 O ktober 1976, dimana ditegaskan bahwa : "Bunga yang diperjanjikan adalah $20 \%$ sebulan tidak diperbolehkan, karena tidak sesuai dengan perikemanusiaan dan keadilan".

Membaca pasal-pasal Kitab Undang-Undang Hukum Perdata, yaitu Pasal 1243 sampai dengan Pasal 1250 tentang ganti rugi, maka tidak satu pun dari pasal-pasal tersebut yang dapat dipakai untuk dijadikan pedoman, bagaimana cara yang ditempuh agar ganti rugi dapat dihitung secara tepat agar seseorang yang mendapat kerugian tidak mendapatkan perhitungan secara berlebih atau mungkin kurang, sehingga orang tersebut telah merasa diposisikan semestinya, seandainya perjanjian terlaksana. Dalam Praktek yang muncul, maka gugatan ganti rugi atas dasar wanprestasi, akan ditempuh dengan cara merinci seluruh daftar kerugian yang telah terjadi dalam materi gugatan, baik yang menyangkut kerugian yang dialami secara nyata maupun keuntungan yang hilang sebagai akibat wan prestasi. J urisprudensi mengenai hal ini menunjukkan bahwa tanpa perincian yang jelas dan kongkrit serta didukung bukti-bukti yang kuat, maka gugatan ganti rugi semacam itu tidak dapat diterima.

\section{Simpulan}

Dari uraian yang telah dipaparkan dalam pembahasan di atas maka dapat disimpulkan : 1) Putusan Pengadilan Negeri Surakarta, yang mengkualifikasikan tindakan melanggar perjanjian atau kesanggupan membayar sejumlah sebagai wanprestasi, yaitu karena pihak debitur tidak melakukan pembayaran tepat waktu sesuai yang diperjanjikan atau kesanggupan. 2) Pertimbangan hukum putusan Pengadilan Negeri Surakarta tersebut berdasarkan pada akte autentik yaitu perjanjian notariil atau surat pengakuan tertulis tentang kesanggupan membayar, sehingga karenanya tuntutan ganti rugi atas dasar wanprestasi ters ebut dikabulkan untuk sebagian, yaitu hanya mengabulkan ganti rugi terhadap halhal yang secara kongkrit dan nyata-nyata diderita dan kemudian dilakukan penilaian secara obyektif, yaitu meliputi kerugian riil yang diderita kreditur dan perhitungan mengenai bunganya.

\section{E. Saran}

1. Untuk menyatukan persepsi yang sama tentang praktek hukum dan metode penentuan besar kecilnya ganti rugi, dalam konteks penemuan hukum oleh hakim, agar dapat menghasilkan putusan hukum yang berwibawa, maka diperlukan penyusunan materi berbagai metode penentuan hukum mengenai praktek penentuan ganti rugi, dan sekaligus metode penemuan hukum sebagai acuan bagi para hakim dalam menjalankan tugas yang diamanatkan undang-undang.

2. Sebaiknya aturan hukum yang ada dalam Kitab Undang-Undang Hukum Perdata, khususnya yang menyangkut tentang ganti rugi yaitu Pasal 1243 sampai dengan Pasal 1252 , dilakukan pengaturan ulang dalam dan sudah saatnya diadopsi dalam materi Rancangan Undang-Undang Hukum Perdata Nasional dan diharapkan tidak hanya mengatur asasasasnya saja tetapi juga mengatur metodemetode penentuan ganti rugi yang dapat dijadikan pedoman oleh hakim.

3. Dalam konteks putusan hakim sebagai judge made law, kiranya hakim dalam praktek penentuan ganti rugi, dituntut agar mengindahkan asas-asas hukum tertulis seperti : asas kebebasan berkontrak, asas etiket baik, causa yang halal maupun asasasas hukum yang tidak tertulis akan tetap hidup dalam masyarakat, seperti halnya asas kesusilaan, asas kepantasan, asas kepatutan, sehingga fungsi hukum benar-benar berjalan. 


\section{Daftar Pustaka}

\section{Buku Literatur :}

Abdulkadir Muhammad. 2002. Hukum Perikatan. Bandung: Citra Aditya Bakti.

Adi Sulistiyono. 2006. Mengembangkan Paradigma Non-Ligitasi di Indonesia. Surakarta: Sebelas Maret University P ress.

Ahmad Kamil M. Fauzan. 2008. Kaidah-kaidah Hukum Yurisprudensi. J akarta: Prenada Media Group. Bambang Sunggono. 2003. Metodologi Penelitian Hukum. Jakarta: Raja Grafindo Persada.

Burhan Asshofa. 1996. Metode Penelitian Hukum. J akarta: Rineka Cipta.

C.F.G. Sunaryati Hartono. 1991. Politik Hukum Menuju Satu Sistem Hukum Nasional. O riginal from. the University of California. Bandung: Alumni.

J. Satrio. 1995. Perikatan, Perikatan Yang Lahir dari Perjanjian. Buku 1. Bandung: Penerbit Citra Aditya Bakti.

Lili Rasjidi dan I.B. Wyasa Putra. 1993. Hukum Sebagai Suatu Sistem. Bandung: Remaja Rosdakarya. Maruarar Siahaan. 1998. Hukum Acara Mahkamah Konstitusi Republik Indonesia. Jakarta: Sinar Grafika. Purwahid Patrik. 1994. Dasar-dasar Hukum Perikatan. Bandung: Mandar Maju.

Qodri Azizy. 2006. Menggagas Hukum Progresif Indonesia. Yogyakarta: Pustaka Pelajar.

Rianto Adi. 2004. Metodologi Penelitian Sosial dan Hukum. J akarta: Granit.

Setiono. 2005. Pemahaman terhadap Metodologi Penelitian Hukum. Surakarta: Program Studi IImu Hukum Pascasarjana UNS.

S oerjono Soekanto. 2002. Pengantar Penelitian Hukum. J akarta: UI Press.

Soerjono Soekanto dan Sri Mamuji. 1983. Penelitian Hukum Normatif Suatu Tinjauan Singkat. J akarta: Rajawali.

Sudikno Mertokusumo. 1986. Mengenal Hukum, Suatu Pengantar. Yogyakarta: Liberty. 1984. Bunga Rampai Ilmu Hukum. Yogyakarta: Liberty.

Sudikno Mertokusumo dan A. Pitlo. 1993. Bab-bab tentang Penemuan Hukum. Bandung: PT Citra Aditya Bakti.

\section{Makalah dan J urnal :}

P. Wignyosumarto. 2006. "Peran dan Tugas Hakim Pengawas". Varia Peradilan. Nomor 246 Tahun XXI.

Siti Ismijati J enie. 2001. "Berbagai Persoalan Yuridis Yang Timbul Berkenaan Dengan Klausula Kejadian Kelalaian (Event Of Default) Di Dalam Perjanjian Sewa Guna Usaha Yang Berkembang Di Indonesia". M imbar Hukum Fakultas Hukum Universitas Gadjah Mada. Vol. 38/II/2001. Yogyakarta.

\section{Perundang-Undangan :}

Undang-Undang Dasar 1945.

Garis-garis Besar Haluan Negara.

Kitab Undang-Undang Hukum Perdata.

Undang-Undang Nomor 4 tahun 2004 tentang Kekuasaan Kehakiman. 
.J urnal Pasca Sarjana Hukum UNS Vol V No. 1 J anuari-J uni 2017

Undang-Undang Nomor 5 Tahun 2004 tentang Perubahan Atas Undang-Undang Nomor 14 Tahun 1985 tentang Mahkamah Agung.

Yurisprudensi Mahkamah Agung Republik Indonesia.

\section{Internet :}

Yuni Rido. Politik dan Strategi Nasional. Rabu. 27 Mei 2015. http://yunirido.blogspot.co.id/2015_05_01_ archive.html. 